\title{
Antidiabetic Effect of Aqueous Root Extract of Carica papaya L. in Alloxan-induced Diabetic Rats
}

\author{
Rachel Nimenibo-Uadia* Kanayo Nwachukwu \\ Department of Biochemistry, University of Benin, Benin City, Nigeria.
}

\begin{abstract}
Antihyperglycaemic effect of aqueous root extract of male Carica papaya L. (Family: Caricaceae) was investigated in alloxan-induced albino rats. $500 \mathrm{mg} / \mathrm{kg}$ body weight extract was administered by gavage orally twice daily for 7 days. Consequent upon induction of diabetes, the resulting raised levels of blood glucose, cholesterol, bilirubin, alanine aminotransferase (ALT) and alkaline phosphatase (AP) were significantly $(p<0.05)$ reduced after one week of administering the extract. In contrast, the significant decrease in total plasma protein of rats injected with alloxan were significantly $(\mathrm{p}<0.05)$ increased following administration of extract compared to diabetic control rats. The results indicate the aqueous extract of male Carica papaya root ameliorated hyperglycaemia and hypercholesterolaemia lending credence to its folkloric use as treatment for diabetes mellitus. Furthermore, the extract ameliorated hepatic tissue injuries in the diabetic rats.
\end{abstract}

Keywords: Carica papaya L., antihyperglycaemic, diabetic rats, aqueous, root, extract

DOI: $10.7176 / \mathrm{JNSR} / 10-6-01$

Publication date:March $31^{\text {st }} 2020$

\section{Introduction}

Diabetes mellitus is a chronic disorder of carbohydrate, fat and protein metabolism. A relative or absolute deficiency in insulin secretory response, which translates into carbohydrate (glucose) use, is a characteristic feature of diabetes (James et al., 2003). One type of classification was proposed in 1997 by the American Diabetes Association based on etiology. These are diabetes types 1 and 2 . Type 1 diabetes formerly called InsulinDependent Diabetes Mellitus (IDDM) or juvenile onset diabetes accounts for $5 \%$ to $10 \%$ of all cases of diabetes. In type 2 diabetes, up to $80 \%$ of patients are involved. It was previously called Non-Insulin-Dependent Diabetes mellitus (NIDDM) or adult onset diabetes (Frier \& Fisher, 2002). Long term complications include retinal damage, nerve damage, microvascular disease, cardiovascular disease, liver damage, renal failure etc. if the disease is not adequately controlled.

Epidemiological survey indicated that diabetes mellitus, among other debilitating pathologic conditions, is the leading cause of morbidity and mortality of all age groups worldwide (Matough et al., 2012). The World Health Organisation in the year 2000 reported that $2.8 \%$ of the global population was afflicted with diabetes mellitus and epidemiological projections showed that the number is expected to rise to $4.4 \%$ by the year 2030 (Wild et al., 2004). These statistics underscore the enormous public health concerns of diabetes mellitus. There is therefore a need to improve already established remedies and to develop new ones. In view of this, the WHO expert committee on diabetes mellitus (WHO, 1980) recommended that it is important to investigate the effect of agents of plant origin used in traditional medicine.

Carica papaya L. (Family: Caricaceae) is a herbaceous dicotyledonous plant that may produce fruits for many years. The plant usually has a single trunk with several well developed branches. The melon-like fruits vary in size and shape, and hang from short thick peduncles at the leaf axel. Its flowers are mostly dioecious and resemble each other until they start to develop sexual organs. The species is polygamous and can be classified into three sex types: male staminate, hermaphrodite (bisexual) and female pistillate. A few male plants in a plantation help pollination and development of large fruits. The plant, originally a native of America is now extensively grown in all warm countries (Dutta, 1970).

C. papaya more commonly known as papaw has been used as a diuretic (the roots and leaves), anthelmintic (the leaves and seeds) and fruits to treat bilious conditions. Parts of the plant are also used to combat dyspepsia and other digestive disorders (papaya contains proteolytic enzymes which soothes the stomach and aids digestion), and a liquid portion has been used to reduce enlarged tonsils (Oliver-Bever, 1980; Duke, 1985). In addition, the juice is used for warts, cancers, tumors, corns and skin defects while the root is said to help tumors of the uterus. This study aims at investigating the antidiabetic claims of the aqueous extract of male C. papaya root by studying indices of diabetes mellitus such as glucose, cholesterol as well as total protein, bilirubin and liver marker enzymes using albino rats.

\section{Materials and Methods}

2.1 Chemicals/Reagents

Alloxan monohydrate was purchased from Sigma Chemical Company, St. Louis, MO, USA. Assay kits used in estimating glucose, cholesterol, total protein, bilirubin, alanine aminotransferase and alkaline phosphatase were 
purchased from Randox Laboratory Ltd., UK.

\subsection{Animals}

Twenty-five (25) albino rats of the Sprague-Dawley strain weighing between $100 \mathrm{~g}$ and $230 \mathrm{~g}$ were purchased from the Nigerian Institute for Medical Research, Yaba, Lagos. They were housed in clean metal cages at a temperature of $25 \pm 2{ }^{\circ} \mathrm{C}$ with 12 hours light/dark cycles. They were acclimatized for one week and fed on grower's pellets (Bendel Feed Mill, Ewu, Edo State, Nigeria) and given water ad libitum. Animals were handled in accordance with internationally accepted principles for laboratory animal use and care (NIH Publication 85 - 93, revised, 1985).

\subsection{Induction of Diabetes Mellitus}

Diabetes mellitus was induced on two consecutive days by the intraperitoneal injection of freshly prepared $100 \mathrm{mg} / \mathrm{kg}$ body weight of alloxan monohydrate (Sigma Chemical Company, St. Louis, MO, USA) dissolved in distilled water. Twenty-four (24) hours after the second alloxan injection, fasting blood (16 h) was drained from the tail veins of conscious rats and analysed. Only rats with fasting blood glucose above $120 \mathrm{mg} / \mathrm{dl}$ were used for the diabetes study.

\subsection{Pharmacological Evaluation}

Twenty-five (25) rats were randomly divided into 3 groups with Groups A and B having ten (10) rats each and Group C five (5). $500 \mathrm{mg} / \mathrm{kg}$ body weight of the aqueous root extract of male Carica papaya was administered to Group B rats orally by gavage twice daily.

Group A: Diabetic rats received distilled water (Diabetic control)

Group B: Diabetic rats received C. papaya aqueous root extract (Diabetic treated)

Group C: Normal rats received distilled water (Normal control)

\subsection{Plant Material and Extraction}

Fresh roots were collected from male Carica papaya growing in a garden at the University of Benin, Benin City, Nigeria and identified (Voucher Number $\mathrm{UBH}_{\mathrm{C}} 342$ ) at the Plant Biology and Biotechnology Department Herbarium of the same university. The roots were then washed under running tap water to remove soil and debris. They were cut into tiny pieces, sun-dried and oven-dried (Gallenkamp, UK) at $60{ }^{\circ} \mathrm{C}$ till a constant weight was recorded. The dried roots were milled (Thomas-Wiley Machine, England) and the sieved powdered sample kept in sealed glass bottles till needed.

Exactly $250 \mathrm{~g}$ of the powdered root of C. papaya were extracted with 1.5 litres of distilled water in a soxhlet extraction apparatus for 8 hours. The liquid extract was concentrated using a rotary evaporator (Gallenkamp, UK) and the semi-solid dried extract was further dried to a constant weight over a steam bath (Gallenkamp, UK) at 60 ${ }^{0} \mathrm{C}$, giving a $8.4 \%$ yield. $5 \mathrm{~g}$ of the extract was made up to $100 \mathrm{ml}$ and used as stock crude drug.

\subsection{Blood Collection}

Prior to blood collections, feed was withdrawn from all rats but were allowed water ad libitum. Fasting blood was drained from the veins of conscious rats into fluoride citrate treated bottles for glucose analysis and into lithium oxalate specimen bottles for plasma used for other analysis. Blood samples were collected prior to induction of diabetes (baseline), 24 hours after second alloxan injection and then on alternate days thereafter during administration of extract. Blood samples were centrifuged at 3,500 r.p.m. (MSE Minor Bench Centrifuge, London) for $10 \mathrm{~min}$ and serum/plasma analysed using assay kits from Randox Laboratory Ltd, UK.

\subsection{Biochemical Analysis}

Serum glucose concentration was estimated using enzymatic colorimetric kits (Randox Laboratory Ltd., UK) in which the glucose oxidase/peroxidase/4-aminophenazone method of Tietz (1990) was adopted. Absorbance was read at $500 \mathrm{~nm}$ (Pye Unicam SP 1800 Ultraviolet Spectrophotometer). Plasma cholesterol concentration was estimated as described in the Randox Kit where the indicator quinoneimine is formed from hydrogen peroxide and 4-amino antipyrene in the presence of phenol and peroxidase. Absorbance was read at $500 \mathrm{~nm}$. Bilirubin was determined by the reaction with diazolized sulfanilic acid and absorbances read at $578 \mathrm{~nm}$. Plasma total protein was determined using the biuret method for detecting the presence of peptide bonds (Tietz, 1995). Briefly, 0.02 $\mathrm{ml}$ of plasma, standard protein solution and reagent blank were pipetted into 3 different tubes and $1.0 \mathrm{ml}$ biuret reagent solution added. The mixture was incubated for $30 \mathrm{~min}$ at $25^{\circ} \mathrm{C}$ and absorbance of the plasma and standard measured against the reagent blank at $546 \mathrm{~nm}$.

\subsection{Assessment of Liver Enzymes}

The activities of plasma alanine aminotransferase (ALT) and alkaline phosphatase (AP) were assayed using 
colorimetric assay kits (Randox Laborator Ltd., UK) according to manufacturer's instructions and values expressed in IU/L.

\subsection{Statistical Analysis}

Results are presented as means \pm SD of triplicate determinations. The differences between the means of test and control groups were analysed by student t-test. Statistical significance was set at a value of $\mathrm{p} \leq 0.05$.

\section{Results}

Results obtained are displayed in Tables 1 to 6 . The blood glucose levels of rats before alloxan injection (Day 0 , baseline values) and after (Days 3, 5, 7 and 9) are presented in Table 1.

Administration of $C$. papaya lowered serum glucose concentration in the diabetic treated rats (Group B) compared to control and baseline values $(\mathrm{p}<0.05)$. Following one week administration of the extract, was a $56.65 \%$ decrease in serum glucose level compared with control rats (Group A).

Table 1: Effect of male C. papaya aqueous root extract on serum glucose concentrations $(\mathrm{mg} / \mathrm{dl})$ in alloxan-induced diabetic rats. Treatment began on Day 3

\begin{tabular}{|c|c|c|c|c|}
\hline Day & $\begin{array}{l}\text { Diabetic Control } \\
\text { Rats (Group A) }\end{array}$ & $\begin{array}{l}\text { Diabetic Treated } \\
\text { Rats (Group B) }\end{array}$ & $\begin{array}{l}\text { Normal Control } \\
\text { Rats (Group C) }\end{array}$ & Significance \\
\hline \multicolumn{5}{|l|}{ Pre-alloxan } \\
\hline 0 & $\begin{array}{c}74.64 \pm 13.00^{\mathrm{a}} \\
(7)\end{array}$ & $\begin{array}{l}82.50 \pm 9.90^{\mathrm{b}} \\
\text { (9) }\end{array}$ & $\begin{array}{c}74.14 \pm 14.20^{c} \\
(5)\end{array}$ & $\begin{array}{l}{ }^{\mathrm{ab}} \mathrm{p}>0.05 \\
\mathrm{ac} p>0.05\end{array}$ \\
\hline \multicolumn{5}{|l|}{ Post-alloxan } \\
\hline 3 & $\begin{array}{c}127.24 \pm 42.00^{\mathrm{d}} \\
(7)\end{array}$ & $\begin{array}{c}114.90 \pm 13.40^{\mathrm{e}} \\
(9)\end{array}$ & - & $\begin{array}{l}\text { ad } p<0.05 \\
\text { be } p<0.05\end{array}$ \\
\hline 5 & $\begin{array}{c}137.26 \pm 33.6^{f} \\
(7)\end{array}$ & $\begin{array}{c}88.50 \pm 16.80^{g} \\
(9)\end{array}$ & $\begin{array}{c}69.90 \pm 4.40^{\mathrm{h}} \\
(5)\end{array}$ & $\begin{array}{l}{ }^{\mathrm{fg}} \mathrm{p}<0.05 \\
\mathrm{fh} p<0.05\end{array}$ \\
\hline 7 & $\begin{array}{c}121.26 \pm 29.90^{\mathrm{i}} \\
(7)\end{array}$ & $\begin{array}{c}72.30 \pm 9.80^{j} \\
(9)\end{array}$ & $\begin{array}{c}65.00 \pm 13.40^{\mathrm{k}} \\
(5)\end{array}$ & $\begin{array}{l}{ }^{\mathrm{ij}} \mathrm{p}<0.05 \\
{ }_{\mathrm{ik}} \mathrm{p}<0.05\end{array}$ \\
\hline 9 & $\begin{array}{c}96.87 \pm 24.80^{1} \\
(7)\end{array}$ & $\begin{array}{c}59.50 \pm 8.90^{\mathrm{m}} \\
(9) \\
\end{array}$ & $\begin{array}{c}67.74 \pm 7.00^{\mathrm{n}} \\
(5)\end{array}$ & $\begin{array}{l}{ }^{\operatorname{lm}} \mathrm{p}<0.05 \\
\ln \mathrm{p}<0.05\end{array}$ \\
\hline
\end{tabular}

$(\mathrm{n})=$ number of rats. Values are means $\pm \mathrm{SD}$ of triplicate determinations

Table 2 shows the concentrations of plasma cholesterol in rats before and after treatments. Injection of rats with alloxan caused a significant increase $(p<0.05)$ in plasma cholesterol concentrations in the diabetic rats (Groups A and B) when compared to the normal control rats (Group C). Administration of the extract caused a significant $(\mathrm{p}<0.05)$ lowering of cholesterol levels in the treated diabetic rats.

Table 2: Effect of male Carica papaya aqueous root extract on plasma cholesterol concentrations (mg/dl) in alloxan-induced diabetic rats. Treatment began on Day 3

\begin{tabular}{|c|c|c|c|c|}
\hline Day & $\begin{array}{c}\text { Diabetic Control } \\
\text { Rats (Group A) }\end{array}$ & $\begin{array}{c}\text { Diabetic Treated } \\
\text { Rats (Group B) }\end{array}$ & $\begin{array}{l}\text { Normal Control } \\
\text { Rats (Group C) }\end{array}$ & Significance \\
\hline \multicolumn{5}{|l|}{ Pre-alloxan } \\
\hline 0 & $\begin{array}{c}69.74 \pm 13.52^{\mathrm{a}} \\
(7)\end{array}$ & $\begin{array}{c}73.70 \pm 8.43^{b} \\
\text { (9) }\end{array}$ & $\begin{array}{c}74.16 \pm 18.80^{c} \\
(5)\end{array}$ & $\begin{array}{l}{ }^{\mathrm{ab}} \mathrm{p}>0.05 \\
\mathrm{ac} p>0.05\end{array}$ \\
\hline \multicolumn{5}{|c|}{ Post-alloxan } \\
\hline 3 & $\begin{array}{c}101.90 \pm 22.30^{\mathrm{d}} \\
(7)\end{array}$ & $\begin{array}{c}105.0 \pm 9.93^{\mathrm{e}} \\
(9)\end{array}$ & - & $\begin{array}{l}\text { ad } p<0.05 \\
\text { be } p<0.05\end{array}$ \\
\hline 5 & $\begin{array}{c}121.76 \pm 22.30^{f} \\
(7)\end{array}$ & $\begin{array}{c}86.10 \pm 7.52^{\mathrm{g}} \\
(9)\end{array}$ & $\begin{array}{c}67.20 \pm 14.90^{\mathrm{h}} \\
(5)\end{array}$ & $\begin{array}{l}\text { fg } p<0.05 \\
\text { fh } p<0.05\end{array}$ \\
\hline 7 & $\begin{array}{c}117.20 \pm 19.90^{\mathrm{i}} \\
(7)\end{array}$ & $\begin{array}{c}91.10 \pm 3.04^{j} \\
(9)\end{array}$ & $\begin{array}{c}74.78 \pm 8.40^{\mathrm{k}} \\
(5)\end{array}$ & $\begin{array}{l}{ }^{\mathrm{ij}} \mathrm{p}<0.05 \\
{ }_{\mathrm{ik}} \mathrm{p}<0.05\end{array}$ \\
\hline 9 & $\begin{array}{c}116.09 \pm 17.70^{1} \\
(7)\end{array}$ & $\begin{array}{c}82.10 \pm 9.34^{\mathrm{m}} \\
(9) \\
\end{array}$ & $\begin{array}{c}65.60 \pm 7.30^{\mathrm{n}} \\
(5)\end{array}$ & $\begin{array}{l}{ }^{\operatorname{lm}} \mathrm{p}<0.05 \\
{ }^{\ln } \mathrm{p}<0.05\end{array}$ \\
\hline
\end{tabular}

(n) = number of rats. Values are means \pm SD of triplicate determinations

Alloxan injection caused a statistically significant $(\mathrm{p}<0.05)$ decrease in total protein concentration in the rats (Table 3).

Following one week oral administration of the extract, total protein concentration in the treated rats increased significantly $(\mathrm{p}<0.05)$. 
Table 3: Effect of male Carica papaya aqueous root extract on total protein concentrations (mg/dl) in alloxaninduced diabetic rats. Treatment began on Day 3

\begin{tabular}{|c|c|c|c|c|}
\hline Day & $\begin{array}{l}\text { Diabetic Control } \\
\text { Rats (Group A) }\end{array}$ & $\begin{array}{c}\text { Diabetic Treated } \\
\text { Rats (Group B) }\end{array}$ & $\begin{array}{l}\text { Normal Control } \\
\text { Rats (Group C) }\end{array}$ & Significance \\
\hline \multicolumn{5}{|l|}{ Pre-alloxan } \\
\hline 0 & $10.70 \pm 1.03^{\mathrm{a}}$ & $\begin{array}{c}12.40 \pm 1.68^{b} \\
(9)\end{array}$ & $\begin{array}{c}11.40 \pm 3.91^{\mathrm{c}} \\
(5)\end{array}$ & $\begin{array}{l}{ }^{\mathrm{ab}} \mathrm{p}>0.05 \\
\mathrm{ac} p>0.05\end{array}$ \\
\hline \multicolumn{5}{|l|}{ Post-alloxan } \\
\hline 3 & $6.54 \pm 1.69^{d}$ & $\begin{array}{c}6.30 \pm 1.02^{\mathrm{e}} \\
(9) \\
\end{array}$ & - & $\begin{array}{l}{ }^{\text {ad }} \mathrm{p}<0.05 \\
\text { be } \mathrm{p}<0.05\end{array}$ \\
\hline 5 & $5.74 \pm 1.00^{\mathrm{f}}$ & $\begin{array}{c}6.74 \pm 1.21^{\mathrm{g}} \\
(9)\end{array}$ & $\begin{array}{c}8.76 \pm 1.91^{\mathrm{h}} \\
(5)\end{array}$ & $\begin{array}{l}\text { fg } p>0.05 \\
\text { fh } p<0.05\end{array}$ \\
\hline 7 & $5.10 \pm 1.30^{\mathrm{i}}$ & $\begin{array}{c}7.78 \pm 1.79^{j} \\
(9)\end{array}$ & $\begin{array}{c}8.60 \pm 1.66^{\mathrm{k}} \\
(5)\end{array}$ & $\begin{array}{l}{ }^{\mathrm{ij}} \mathrm{p}<0.05 \\
{ }_{\mathrm{ik}} \mathrm{p}<0.05\end{array}$ \\
\hline 9 & $4.10 \pm 1.45^{1}$ & $\begin{array}{c}10.40 \pm 1.60^{\mathrm{m}} \\
(9)\end{array}$ & $\begin{array}{c}8.90 \pm 1.73^{n} \\
(5)\end{array}$ & $\begin{array}{l}{ }^{\operatorname{lm}} \mathrm{p}<0.05 \\
{ }^{\ln } \mathrm{p}<0.05\end{array}$ \\
\hline
\end{tabular}

(n) = number of rats. Values are means \pm SD of triplicate determinations

Induction of diabetes mellitus significantly $(\mathrm{p}<0.05)$ raised total plasma bilirubin concentrations. Administration of diabetic rats with the extract caused a $98.68 \%$ reduction after one week.

Table 4: Effect of male Carica papaya aqueous root extract on plasma total bilirubin in alloxan-induced diabetic rats. Treatment began on Day 3

\begin{tabular}{|c|c|c|c|c|}
\hline Day & $\begin{array}{l}\text { Diabetic Control } \\
\text { Rats (Group A) }\end{array}$ & $\begin{array}{c}\text { Diabetic Treated } \\
\text { Rats (Group B) }\end{array}$ & $\begin{array}{l}\text { Normal Control } \\
\text { Rats (Group C) }\end{array}$ & Significance \\
\hline \multicolumn{5}{|c|}{ Pre-alloxan } \\
\hline 0 & $1.06 \pm 0.23^{\mathrm{a}}$ & $\begin{array}{c}1.20 \pm 2.50^{\mathrm{b}} \\
(9)\end{array}$ & $\begin{array}{c}1.34 \pm 0.18^{c} \\
(5)\end{array}$ & $\begin{array}{l}{ }^{\mathrm{ab}} \mathrm{p}>0.05 \\
\mathrm{ac} p>0.05\end{array}$ \\
\hline \multicolumn{5}{|c|}{ Post-alloxan } \\
\hline 3 & $2.73 \pm 2.28^{\mathrm{d}}$ & $\begin{array}{c}3.80 \pm 3.10^{\mathrm{e}} \\
(9)\end{array}$ & - & $\begin{array}{l}\text { ad } \mathrm{p}<0.05 \\
\text { be } \mathrm{p}<0.05\end{array}$ \\
\hline 5 & $2.04 \pm 1.02^{\mathrm{f}}$ & $\begin{array}{c}1.40 \pm 1.30^{\mathrm{g}} \\
(9)\end{array}$ & $\begin{array}{c}1.10 \pm 0.16^{\mathrm{h}} \\
(5)\end{array}$ & $\begin{array}{l}\text { fg } \mathrm{p}<0.05 \\
\text { fh }{ }_{\mathrm{p}}<0.05\end{array}$ \\
\hline 7 & $1.65 \pm 0.48^{\mathrm{i}}$ & $\begin{array}{c}0.04 \pm 0.03^{j} \\
(9)\end{array}$ & $\begin{array}{c}1.26 \pm 0.30^{\mathrm{k}} \\
(5)\end{array}$ & $\begin{array}{l}{ }^{i j} p<0.05 \\
{ }^{i k} p>0.05\end{array}$ \\
\hline 9 & $1.46 \pm 0.72^{1}$ & $\begin{array}{c}0.05 \pm 0.04^{\mathrm{m}} \\
(9)\end{array}$ & $\begin{array}{c}1.16 \pm 0.11^{\mathrm{n}} \\
(5)\end{array}$ & $\begin{array}{l}{ }_{\ln }^{\operatorname{lm}} \mathrm{p}<0.05 \\
\mathrm{ln}>0.05\end{array}$ \\
\hline
\end{tabular}

(n) $=$ number of rats. Values are means \pm SD of triplicate determinations

Tables 5 and 6 show the results for the effect of extract on some marker enzymes in liver disease. Alloxan induction caused significant increases $(p<0.05)$ in plasma Alanine aminotransferase (ALT) activities. Administration of extract caused a statistically significant $(\mathrm{p}<0.05)$ reduction after one week. Plasma alkaline phosphatase (AP) activities also increased significantly $(\mathrm{p}<0.05)$ upon alloxan induction. Administration of the extract elicited a $74.03 \%$ reduction after one week (Table 6).

Table 5: Effect of male Carica papaya aqueous root extract on plasma Alanine aminotransferase activity (IU/L) in alloxan-induced diabetic rats. Treatment began on Day 3

\begin{tabular}{|c|c|c|c|c|}
\hline Day & $\begin{array}{l}\text { Diabetic Control } \\
\text { Rats (Group A) }\end{array}$ & $\begin{array}{c}\text { Diabetic Treated } \\
\text { Rats (Group B) }\end{array}$ & $\begin{array}{l}\text { Normal Control } \\
\text { Rats (Group C) }\end{array}$ & Significance \\
\hline \multicolumn{5}{|c|}{ Pre-alloxan } \\
\hline 0 & $\begin{array}{c}23.26 \pm 11.20^{\mathrm{a}} \\
(7)\end{array}$ & $\begin{array}{c}22.70 \pm 1.30^{\mathrm{b}} \\
(9)\end{array}$ & $\begin{array}{c}25.30 \pm 5.80^{c} \\
(5)\end{array}$ & $\begin{array}{l}{ }^{\mathrm{ab}} \mathrm{p}>0.05 \\
{ }^{\mathrm{ac}} \mathrm{p}>0.05\end{array}$ \\
\hline \multicolumn{5}{|c|}{ Post-alloxan } \\
\hline 3 & $\begin{array}{c}28.04 \pm 14.80^{\mathrm{d}} \\
(7)\end{array}$ & $\begin{array}{c}29.40 \pm 3.00^{\mathrm{e}} \\
\text { (9) }\end{array}$ & - & $\begin{array}{l}\text { ad } p<0.05 \\
\text { be } p<0.05\end{array}$ \\
\hline 5 & $28.84 \pm 8.57^{\mathrm{f}}$ & $\begin{array}{c}29.80 \pm 4.40^{g} \\
\text { (9) }\end{array}$ & $\begin{array}{c}17.34 \pm 6.36^{\mathrm{h}} \\
(5)\end{array}$ & $\begin{array}{l}{ }^{\mathrm{fg}} \mathrm{p}>0.05 \\
\mathrm{fh} p<0.05\end{array}$ \\
\hline 7 & $29.24 \pm 6.23^{\mathrm{i}}$ & $\begin{array}{c}25.30 \pm 1.75^{\mathrm{j}} \\
(9)\end{array}$ & $\begin{array}{c}18.90 \pm 6.47^{\mathrm{k}} \\
(5)\end{array}$ & $\begin{array}{l}{ }^{\mathrm{ij}} \mathrm{p}<0.05 \\
{ }_{\mathrm{ik}} \mathrm{p}<0.05\end{array}$ \\
\hline 9 & $29.76 \pm 7.73^{1}$ & $\begin{array}{c}20.40 \pm 2.37^{\mathrm{m}} \\
(9)\end{array}$ & $\begin{array}{c}20.06 \pm 3.09^{n} \\
(5)\end{array}$ & $\begin{array}{l}{ }^{\operatorname{lm}} \mathrm{p}<0.05 \\
{ }^{\ln } \mathrm{p}<0.05\end{array}$ \\
\hline
\end{tabular}

$(\mathrm{n})=$ number of rats. Values are means $\pm \mathrm{SD}$ of triplicate determinations 
Table 6: Effect of male Carica papaya aqueous root extract on plasma alkaline phosphatase activity (IU/L) in alloxan-induced diabetic rats. Treatment began on Day 3

\begin{tabular}{|c|c|c|c|c|}
\hline Day & $\begin{array}{l}\text { Diabetic Control } \\
\text { Rats (Group A) }\end{array}$ & $\begin{array}{c}\text { Diabetic Treated } \\
\text { Rats (Group B) }\end{array}$ & $\begin{array}{l}\text { Normal Control } \\
\text { Rats (Group C) }\end{array}$ & Significance \\
\hline \multicolumn{5}{|l|}{ Pre-alloxan } \\
\hline 0 & $40.89 \pm 9.33^{\mathrm{a}}$ & $\begin{array}{c}41.30 \pm 7.10^{\mathrm{b}} \\
\text { (9) }\end{array}$ & $\begin{array}{c}36.98 \pm 14.17^{c} \\
(5)\end{array}$ & $\begin{array}{l}{ }^{\mathrm{ab}} \mathrm{p}>0.05 \\
{ }^{\mathrm{ac}} \mathrm{p}>0.05\end{array}$ \\
\hline \multicolumn{5}{|c|}{ Post-alloxan } \\
\hline 3 & $52.21 \pm 8.74^{\mathrm{d}}$ & $\begin{array}{c}59.30 \pm 3.30^{\mathrm{e}} \\
(9)\end{array}$ & - & $\begin{array}{l}\text { ad } \mathrm{p}<0.05 \\
\text { be } \mathrm{p}<0.05\end{array}$ \\
\hline 5 & $46.74 \pm 7.34^{\mathrm{f}}$ & $\begin{array}{c}35.10 \pm 13.90^{\mathrm{g}} \\
(9)\end{array}$ & $\begin{array}{c}34.88 \pm 12.08^{\mathrm{h}} \\
(5)\end{array}$ & $\begin{array}{l}{ }^{\mathrm{fg}} \mathrm{p}<0.05 \\
\mathrm{fh} p<0.05\end{array}$ \\
\hline 7 & $49.50 \pm 6.55^{\mathrm{i}}$ & $\begin{array}{c}15.30 \pm 3.30^{\mathrm{j}} \\
(9)\end{array}$ & $\begin{array}{c}36.16 \pm 11.08^{\mathrm{k}} \\
(5)\end{array}$ & $\begin{array}{l}{ }^{i j} \mathrm{p}<0.05 \\
{ }_{\mathrm{ik}} \mathrm{p}<0.05\end{array}$ \\
\hline 9 & $49.04 \pm 4.60^{1}$ & $\begin{array}{l}15.40 \pm 0.40^{\mathrm{m}} \\
\text { (9) }\end{array}$ & $\begin{array}{c}36.72 \pm 11.91^{\mathrm{n}} \\
(5)\end{array}$ & $\begin{array}{l}{ }^{\operatorname{lm}} \mathrm{p}<0.05 \\
\ln \mathrm{p}<0.05\end{array}$ \\
\hline
\end{tabular}

$(\mathrm{n})=$ number of rats. Values are means \pm SD of triplicate determinations

\section{Discussion}

From earliest of times, diabetes has been treated with plant remedies. The present study investigated the effects of male Carica papaya L. aqueous root extract on some biochemical indices in albino rats with the aim of scientifically establishing its ethnomedicinal use as an antidiabetic agent.

The results obtained show that serum glucose concentration increased significantly $(p<0.05)$ when compared with basal and control values, thus confirming that animals used in this study were made diabetic by alloxan injection. Effective blood glucose control is the key for preventing or reversing diabetic complications (Marx, 2002). The decrease in serum glucose levels following treatment with the extract essentially indicated the effectiveness of $C$. papaya as an antihyperglycaemic agent. This study thus corroborates the work of other researchers who have also reported antihyperglycaemic activities of some plants (Afolayan \& Sunmonu, 2010; Nimenibo-Uadia \& Nwachukwu, 2017).

Cholesterol and other lipids such as triacylglycerols are raised in the diabetic state. The gradual reduction in cholesterol concentration on administration of the extract to diabetic rats shows C. papaya has antihypercholesterolaemic effects. Other workers have reported antihypercholesterolaemic/antihyperlipidaemic effects of some medicinal plants (Janapti, 2015; Nimenibo-Uadia \& Nwachukwu, 2017).

Decreases observed in protein concentration in the diabetic rats may be due to energy metabolism shifting from carbohydrate to other alternative sources such as protein and fat in a diabetic state. Also, protein synthesis by the liver may have been impaired due to damage of the liver by alloxan induction of diabetes.

Reduced plasma total protein may occur due to impaired protein synthesis (as in case of malnutrition), liver disease among others (Whitby et al., 1984). The increase in protein concentrations following one week of treatment by the extract suggest the plant may have restored some functionality to the liver architecture.

Hyperbilirubinaemia as seen in the diabetic animals is one of the conditions indicative of liver damage. The $98.68 \%$ reduction in hyperbilirubinaemia observed after one week administration of the extract suggests C. papaya aqueous root extract may have repaired the damaged liver.

Alanine aminotransferase (ALT) or Aspartate aminotransferase (AST) activity determinations are routine tests for hepatocellular integrity but plasma ALT (which we studied) is more liver-specific (Whitby et al., 1984). Alkaline phosphatase estimation is a routine test for presence of cholestasis in liver damage/disease. Its elevation following alloxan-induction of diabetes in rats in the present study, thus indicates liver damage. Cholestasis is most commonly due to extrahepatic obstruction of the bile ducts (Whitby et al., 1984). Following one week of therapy, there was a decrease in AP activity, thus confirming the healing effects of male C. papaya aqueous root extract on the liver.

\section{Conclusion}

The observations in this study have shown that male C. papaya aqueous root extract is able to ameliorate the biochemical defects indicative of diabetes mellitus. Most antidiabetic plants have been reported to contain saponins, alkaloids, flavonoids, tannins, glycosides that are usually implicated as possessing antidiabetic properties (Harbone et al., 1974; Oliver-Bever, 1980; Nimenibo-Uadia et al., 2017). Thus, the antidiabetic effects of male C. papaya aqueous root may be due to any of these bioactive metabolites.

\section{Acknowledgement}

The authors are grateful to the management of the University of Benin, Benin City, Nigeria for providing the 
facilities used in this study.

\section{References}

Afolayan, A.J. \& Sunmonu, T.O. (2010), "In vivo studies on anti-diabetic plants used in South African herbal medicine", J. Clin. Biochem. Nutr. 47, 98-106.

Duke, J.A. (1985), Handbook of Medicinal Herbs. CRC Press, Florida, USA, p. 17.

Dutta, A.C. (1970), Botany for Degree Students. Oxford University Press, London, p. 809.

Frier, B.L. \& Fisher, B.M. (2002), Diabetes Mellitus In: Davidson's Principles and Practice of Medicine 4th ed. Churchill Livingstone, New York, pp. $642-648$.

Harbone, J.B., Mabry, T.J. \& Mabry, H. (1974), The Flavonoids. Chapman and Hall, London.

James, L.C., Michael, J.C. \& Vikary, K. (2003), Diabetes Mellitus In: Robinson's Basic Pathology 7th ed. Elsevier, India, pp. $641-665$.

Janapti, Y.K. (2015), "Optimise diabetes by herbal medicine: a review”, JAMPS 3(3), 98 -111.

Marx, J. (2002), "Unraveling the Causes of Diabetes", Science, 296, 686 - 689.

Matough, F.A., Budin, S.B., Hamid, Z.A., Alwahaibi, N. \& Mohamed, J. (2012), "The role of oxidative stress and antioxidants in diabetic complications", Sultan Qaboos Univ. Med. J. 12, 5- 18.

Nimenibo-Uadia, R. \& Nwachukwu, K. (2017), "Biochemical Evaluation of Harungana madagascariensis LAM Aqueous Leaf Extract in Diabetic Rats", International Research Journal of Natural Science, 5(2), 1 - 11.

Oliver-Bever, B. (1980), "Oral Hypoglycaemic Plants in West Africa”, Journal of Ethnopharmac. 2, 119 - 127.

Tietz, N.W. (1990), Determination of plasma glucose. In: Clinical Guide to Laboratory Tests. $2^{\text {nd }}$ (ed.) W.B. Saunders Company, Philadelphia, P.A: $246-250$.

Tietz, N.W. (1995), Determination of plasma total protein. In: Clinical Guide to Laboratory Tests. $3^{\text {rd }}$ (ed.) W.B. Saunders Company, Philadelphia, P.A: $518-519$.

WHO (1980), WHO Expert Committee on Diabetes Mellitus. Second report. WHO Technical Report Series, Geneva: 646.

Wild, S., Roglic, G., Green, A., Sicree, R. \& King, H. (2004), “Global prevalence of diabetes: estimates for the year 2000 and projections for 2030", Diabetes Care, 27, 1047 - 1053.

Whitby, L.G., Percy-Robb, I.W. \& Smith, A.F. (1984), Lecture Notes on Clinical Chemistry, $3^{\text {rd }}$ (ed.). Blackwell Scientific Publications, London: pp. 88, 105, 181, 190. 